\title{
ACUTE HYPOTONIA*
}

\author{
BY
}

\author{
VALDEMAR HERTZ. \\ Copenhagen, Denmark
}

AcuTe hypotonia in the closed eyeball has always been said to be a complication in detachment of the retina, but in my work on detachment of the choroid I have found three cases (one of them bilateral) in 1925, 1933, and 1937, in which the hypotonia appeared at the same time as the choroidal detachment. In one case only the choroid became detached; in the others detachment of the retina followed later.

\section{Previous Reports in the Literature}

Verhoeff and Waite (1925) describe a patient who, from the age of 49 to his death from pneumonia at the age of 66 , suffered from a chronic diarrhoea with eight to ten evacuations daily. At the age of 54 he consulted an ophthalmologist with a painful right eye.

Examination showed photophobia, lacrimation, ciliary congestion, and a very deep anterior chamber; the iris was green, there were extensive posterior synechiae, the tension was +3 (later + 2); a detachment of the retina could be made out nasally and below. Trans-illumination seemed defective. Visual acuity was perception of light. The left eye was normal (myopia $0 \cdot 75$, visual acuity $20 / 20 ; 8$ years later, 4 years before the patient's death, a detachment of the retina was diagnosed in the left eye, but no further information could be obtained about this eye.

The right eye was enucleated after the first consultation. The globe was of normal size, the choroid and ciliary body were widely separated from the sclera, and there was no detachment of the retina, and no tumour. The anterior chamber was abnormally deep $(4 \mathrm{~mm}$.) and the iris and lens seemed to be pushed sharply backward; there was a stepformed iris and an abnormally wide filtration angle, with complete posterior synechiae. The vitreous appeared normal without coagulum, which was present in the perichoroidal space, the anterior chamber, the spaces of Fontana and Schlemm's canal. The blood vessels were congested in the episcleral tissue of the limbus and all over the uveal tract. Small haemorrhages were seen in iris, in the ciliary processes, and just behind the ora serrata; the uveal tract was oedematous, and round cells were found in the ciliary body and choroid, the natural vitreous excepted.

Procksch (1933) described a patient seen at Sachs's Clinic in Vienna. He was 58 years old, and had suffered from a violent acute iridocyclitis for one month.

Visual acuity was counting fingers. The ocular tension was normal. Atropine was of no effect, and glaukosan (a mixture of 2 per cent. adrenaline, and 2 per cent. adrenonsolution) was instilled. The pupil was dilated to the maximum, and with the exception of a few posterior synechiae the vitreous was transparent. The fundus and ocular tension were normal, but 4 days after the instillation the picture was quite different. There was intense ciliary congestion, the cornea was quite folded, the anterior chamber was very deep, there was a stepformed iris, and a tremulous iris and lens. The eye was so soft as to give rise to the idea of enophthalmos. A large detachment of the choroid with four elevations was found, and there were many posterior synechiae. A week after the first examination there were symptoms of detachment of the retina, and this detachment became distinct after another week.

After 4 weeks' observation the temporal and nasal detachment of the retina merged with the still,prominent detachments of the choroid, and opacities in the vitreous supervened. Visual

*Received for publication August 20, 1953. 
acuity was now $1 / 24$. It was impossible to measure the ocular tension, though it had increased a little. The patient did return to the clinic after discharge.

Klien (1937) recorded the case of a man aged 65 whose eye had been red and painful for 12 days.

There was mixed injection of the bulb, and the posterior surface of the cornea was covered with fine grey deposits of crystalline appearance. The anterior chamber was very deep and the aqueous humour homogenously cloudy. A few pigment deposits were applied to the anterior lens surface, and there was marked iridodonesis. The vitreous was cloudy. In the superior periphery a dark greyish-brown detachment of the choroid projected downward. Transillumination of the bulb gave a slight shadow in the region of the dark elevation. The ocular tension was $10 \mathrm{~mm} . \mathbf{H g}(\mathrm{Schiötz})$. The visual acuity was counting fingers at $2 \mathrm{ft}$. The visual field with a $10 \mathrm{~mm}$. test object showed no contraction at that time.

During the following 2 months attacks of acute hypotony alternated with rises in the intra-ocular pressure to $28 \mathrm{~mm}$. Hg. During the hypotonic periods the anterior chamber was very deep, and there was marked iridodonesis. Both symptoms disappeared between the attacks.

The dark-brown detachment of the choroid was observed unaltered for 6 weeks, after which an extensive retinal detachment developed. Continuous pain and the thought of a possible tumour necessitated enucleation, which was done in the hypotonic stage. The left eye was normal.

The globe measured $26 \times 24 \mathrm{~mm}$. A detachment of the ciliary body and choroid extended backwards into the equatorial region, and a vicarious retinal detachment with a tear was found in the posterior segment. The anterior chamber was extremely deep, there was stepformed iris, and the chamber angle was widely open. There was marked hyperaemia of the iris, within which many new-formed vessels and disseminated small haemorrhages were seen. The choroidal vessels were widely dilated. The sub-choroidal space and the anterior chamber were filled with a granular exudate between a network of very fine threads. Greeff's vesicles were seen. Small foci of round cell infiltration were scattered throughout the uveal tract and accompanied the long posterior ciliary nerves (a possible explanation of the pain in the eye). In spite of the frequent attacks of hypotony there was no posterior vitreous detachment. Transillumination showed a shadow due to the pigmentation of the choroidal detachment.

Leber (1916) recorded twelve cases (one bilateral) of acute hypotony under the heading of detachment of the retina.

Porsaa (1942) gave a Table with eighteen cases: eight of Leber's, seven from the literature including two earlier cases not mentioned by Leber, and three cases of his own.

Altogether 35 previous cases are made up as follows: Schnabel (1876) two; Samelsohn(1882) one; Nordenson (1887) two; Deutschmann (1893) one; Hirschberg (1898) one, (1907) one; Ginsberg and Simon (1898) one; von Hippel (1908) one; Lauber (1908) four; Vogt (1924) one; Kümmell (1925) one; Halbertsma (1926) one; Beigelman (1929) two; Porsaa (1942) three; Samelsohn (1882) one brief mention; Gonin (1904) two, (1934a, b) five [one with no myopia]; Bret (1907) one; Baurmann (1929) one; Lindner (1931) one; Arruga (1933) one; García Miranda (1945) one.

Myopia was seen in all cases except one reported by Gonin (1934a, b). In one patient (Nordenson, 1887) the hypotony became bilateral after an interval of 8 months.

Twelve of these 35 eyes were enucleated, and one eviscerated, mostly owing to intolerable pain, but now-a-days the treatment comprises hot fomentations, salicylate, and atropine. In ten* of the thirteen eyes removed a large detachment of the ciliary body and choroid was found as well as the retinal detachment: in the other three+ the choroid is not mentioned.

In three of the ten cases the detachment of the choroid was seen with the ophthal-

\footnotetext{
*The ten cases are those of Nordenson (1887), Deutschmann (1893), Ginsberg and Simon (1898), von Hippel (1908)

Bret (1907), Kümmell (1925), Baurmann (1929), Gonin (1934, three cases).

+ The three cases in which the choroid is not mentioned are those of Samelsohn (1882), and Gonin (1904, two cases).
} 
moscope: melanosarcoma was diagnosed in one of the three (Ginsberg and Simon) and reddish-yellow arched reflexes were formed in two (Nordenson, von Hippel), but in these the choroidal detachment was not diagnosed before enucleation.

Among the remaining 22 of the total of 35 cases, choroidal detachment was observed with the ophthalmoscope in two cases (Beigelman, García Miranda) at the same time as the beginning of the hypotony, but it disappeared in a few days.

According to Porsaa (1942), days or months may intervene between the beginning of the retinal detachment and the appearance of hypotony, and the duration of the pain is commonly 3 weeks. Opacities in the vitreous occur in all cases. The period of hypotony lasts as a rule from 4 to 5 weeks.

Müller (1903), operating for retinal detachment with excessive myopia by resection of the sclera, pointed out that detachment of the choroid was nearly always present, and that a yellowish-green serum was evacuated from the subchoroidal space. He thought the lowered tension accompanying retinal detachment to be due to cyclitis, which arose because of this serum which produced the green colour in the iris.

The same type of acute hypotony as is found in the closed bulb also occurs with penetrating lesions of the sclera.

Ladekarl (1935) stated that acute hypotony could rise after a diathermy operation with puncture for retinal detachment. Similar cases are mentioned by Lindner (1931) and Arruga (1933). To Ladekarl's two cases from the State Hospital in Copenhagen, Porsaa (1942) added twelve from the same source during 1936-1942. One of these showed emmetropia, and then as a rule considerable myopia: in six cases the intra-ocular pressure rose again after re-operation, and in one case after the third operation. Usually it rose a few days after the operation, in four cases from 1 to 3 weeks after. The results of operation seem to have been poor in these cases.

Cases of choroidal detachment as a complication of diathermy with puncture for retinal detachment are recorded by Paufique (1939), and by Binkhorst (1939), who communicated cases from Weve's clinic in Utrecht. Schiff-Wertheimer and Frileux (1946) reported cases from Paris. Binkhorst thought that the complication retarded recovery, but had little effect on prognosis. Unfortunately the tension is not mentioned.

Cases with hypotony are mentioned by Lindner (1931) and Gonin (1934a, b) after cauterization with puncture for retinal detachment. Hypotony appeared at the same time as the choroidal detachment, and later disappeared.

In the second case reported by Ladekarl (1935), where the tension was falling 2 days after re-operation for retinal detachment, a red reflex was observed upward in the dilated pupil; I wonder if this reflex was not due to a choroidal detachment. Ladekarl discussed the aetiology of the hypotony, but reached no conclusion.

Leber (1916) thought that the acute hypotony accompanying retinal detachment was due to a considerable reduction of the vitreous, and that the pressure bandage, and spasm of the orbicularis, forced the vitreous through the rupture of the detachment to be resorbed by the chorio-capillaris. This theory does not hold where only choroidal detachment is present, and since the retinal detachment itself is due to the flow of vitreous through the rupture of the retina, it is difficult to understand that further vitreous should be resorbed. 
Lauber (1908) thought that a cyclitis with reduced formation of intra-ocular fluid was the cause of the hypotony, but no such acute cyclitis occurs anatomically with retinal detachment. Müller (1903) expressed the same opinion 5 years before Lauber.

Vogt (1924) and Kümmell (1925) supposed a hypofunction of the ciliary body to be the cause, and Kümmell also suggested alterations in the balance of tension in the vitreous.

Porsaa (1942) described a case of penetrating injury of the bulb with typical acute hypotony. In this case (seen in the State Hospital at Copenhagen in 1941) sclera, choroid, and retina were perforated, and a temporary fistula was formed in the suprachoroidal space; the hole in the sclera was rather small and was very soon closed operatively, and, as the resorption of fluid from this space readily occurs, the hypotony is easily explicable. Porsaa tried to explain acute hypotony in retinal detachment in the closed bulb in the same way, saying that the hypotony was due to free passage of the vitreous to the supra-choroidal space through a hole in the retina and a hole in the choroid.

Certainly the choroid was very thin in some of the cases examined, but no hole was ever found.

In the case of Ginsberg and Simon (1898) there was a haemorrhagic choroidal detachment and a serous detachment of the retina, an impossibility by this theory. In ten of the thirteen cases examined anatomically, a large detachment of the ciliary body and choroid was present, and resorption of fluid from the suprachoroidal space must surely be very difficult in such cases.

The cases without retinal detachment do not support Porsaa's theory. One may ask whether the acute hypotony is not due to a developed detachment of the choroid, which has escaped notice owing to the opacities in the vitreous.

In García Miranda's case, the choroidal detachment only lasted 6 days; but the retinal detachment was unchanged.

The vasomotor nervous system probably plays a prominent part in the aetiology of choroidal detachment. Kümmell's theory that the balance of tension in the vitreous is changed, possibly because of transudation from the vessels and oedema of the tissues, ought also to be taken into consideration.

Unusual conditions of tension take place as the hypotony begins; of two cases (later enucleated and found to present detachment of both choroid and retina), one showed a rise in ocular tension for 3 days, and a reduction on the seventh day, and the other showed a normal tension on the second day and a reduction on the third day. Possibly this has some connection with the difficulty of egress of the albuminous aqueous.

Bret (1907) expressed this opinion:

Quand, dans un oeil aveugle, à la suite d'un décollement de la rétine, surviennent ces trois symptômes caractéristiques: douleurs rapellant celles de l'iritis intense ou du glaucome aigu, diminution du tonus, et réduction considérable du volume de l'oeil, ils indiquent que la choroïde décollée ne secrète plus le liquide intérieur et qu'elle exerce des tiraillements sur le corps ciliaire et les nerfs ciliaires. 
Gonin (1934a) declared:

Dans tous les cas où l'hypotonie avait existé et où j'ai du faire l'examen anatomique de l'oeil, j'avais noté un décollement plus ou moins prononcé du corps ciliaire et de la choroìde; d'autres observateurs avaient fait les mêmes constatations (Leber, Kümmell, Baurmann, etc.).

One thing is certain: acute hypotony in the closed bulb can arise where detachment of the choroid only is present; this condition is probably the expression of a choroidal detachment.

\section{REFERENCES}

Arruga, H. (1933). “'XIV Concilium Ophthalmologicum, Hispania ", vol. 2, part 1, p.86.

BaurmanN, M. (1929). v. Graefes Arch. Ophthal., 122, 415 (p. 438.)

BINKHORST, P. G. (1939). Ophthalmologica (Basel), 98, 363.

BRET, T. (1907). Arch. Ophtal., 27, 544.

Deutschmann, R. H. (1890). Beitr. Augenheilk., 1, Heft 1, p. 41.

García Miranda, A. (1945). Arch. Soc. oftal. hisp.-amer., 5, 664.

Ginsberg, S., and Simon, R. (1898). Zbl. prakt. Augenheilk., 22, 161.

GonIN, J. (1904). Ann. Oculist. (Paris), 132, p. 30, 37. (1934a). Arch. Ophtal., 51, 426, 428.

HAGEN, S. (1920). "Le décollement de la rétine ", Payot, Lausanne. p. 40, 41, 42, 97. Grieg, Bergen. (1921). Klin. Mbl. Augenheilk., 66, 160.

Halbertsma, K. T. A. (1926). Ibid., 77, 86.

HIPPEL, E. voN (1908).. v. Graefes Arch. Ophthal, 68, 38, 58.

HirsCHBERG, J. (1898). Zbl. prakt. Augenheilk., 22, 207. (1907). Ibid., 31, 72 .

KLIEN, B. A. (1937). Amer. J. Ophthal., 20, 812, 817.

KüMmELl, R. (1925). Arch. Augenheilk., 95, 214.

LADERARL, P. M. (1935). Acta ophthal. (Kbh.), 13, 301.

LAUBER, H. (1908). Z. Augenheilk., 20, 208.) (Case 4, p. 211; Cases 5, 6, 7, pp. 212-213).

LEBER, T. (1916). "Handbüch der gesamten Augenheilkunde", ed. A. Graefe and T. Saemisch, Bd. 7, Kap. X (A), p. 1422. 2nd ed., Engelmann, Leipzig.

LiNDNER,' K.' (1931). v. Graefes Arch. Ophthal., 127, p. 177, (pp. 222-224).

.MüLLER, L. (1903). Münch. med. Wschr., 50, 977.

NoRdenson, E. (1887). "Die Netzhautablösung", Case 4, p. 115. Bergmann, Wiesbaden.

PAufiQue, L. (1940). Arch. Ophtal., 3, 1021.

PORSAA, K. (1942). Acta ophthal. (Kbh.), $20,379$.

ProcksCH, M. (1933). Z. Augenheilk., 81, 224.

SAMELSOHN, A. (1882). Ber. ophthal. Ges. Heidelberg, p. 18, 38.

SCFIFF-WERTHEIMER, S., and FRIIEUX, R. (1946). Bull. Soc. franc. Ophtal., 59, $265,279$.

SCHNABEL, J. (1876). Arch. Augenheilk., 5, 50, 69, 71.

VERHOEFF, F. H., and WAITE, J. H. (1925). Trans. Amer. ophthal. Soc., 23, 120.

VoGt, A. (1924). Klin. Mbl. Augenheilk., 72, 335. 